\title{
Spontaneous emission from active dielectric microstructures
}

\section{Søndergaard, Thomas; Tromborg, Bjarne}

Published in:

2000 International Quantum Electronics Conference Digest

Link to article, DOI:

10.1109/IQEC.2000.908170

Publication date:

2001

Document Version

Publisher's PDF, also known as Version of record

Link back to DTU Orbit

Citation (APA):

Søndergaard, T., \& Tromborg, B. (2001). Spontaneous emission from active dielectric microstructures. In 2000 International Quantum Electronics Conference Digest (pp. 224-224). https://doi.org/10.1109/IQEC.2000.908170

\section{General rights}

Copyright and moral rights for the publications made accessible in the public portal are retained by the authors and/or other copyright owners and it is a condition of accessing publications that users recognise and abide by the legal requirements associated with these rights.

- Users may download and print one copy of any publication from the public portal for the purpose of private study or research.

- You may not further distribute the material or use it for any profit-making activity or commercial gain

- You may freely distribute the URL identifying the publication in the public portal

If you believe that this document breaches copyright please contact us providing details, and we will remove access to the work immediately and investigate your claim. 
09.15 QFC4

Variable coherence in determining the scattering parameters of diffuse media using laser speckle

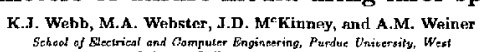

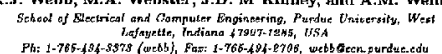

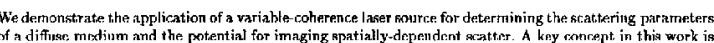

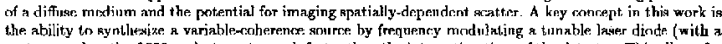

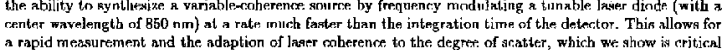
A rapid mesalrement and the adapling
in obtaining the nexessary sensitivity

The epcoklc intonsity statistira arc describod by the contrast ratio, which wo have prcyiously showa can be suppended in the acrylic backgronnd) as the diffite nnodium in a transmission genmetry. The eppeckle contrast ratio dependence upon the source linexidth was measured, with the results shown in Fig. 1. The theoretical

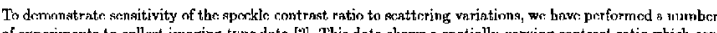

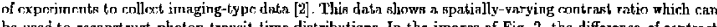

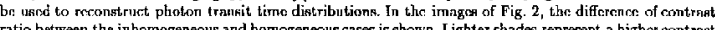
ratio between the inbornogeneous and homogeneous caeses is shown Lighter shades represent a higher contrast a region of higher contrast ratio cortesponding to the localized reduction of scattering introduced by a woid Conversely, in Fig. 2(d), one can see a region of lower contrast tatio due to the localized increase in scattcring

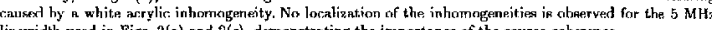

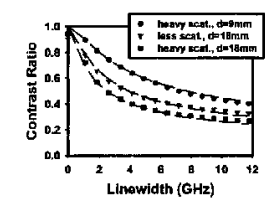

Fig 1. Contrast ratio data as a function of laser
lineviddh for two different acrylics The kymbols are exlineviddh for two different acryliks The kymbols are are

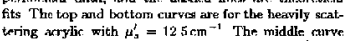
is for the leess seallering resylis with $\mu_{x}^{\prime}=6 \mathrm{rm}^{-1}$. The Beforences

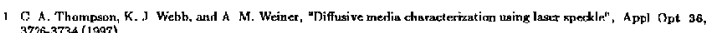

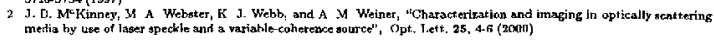

09.30 QFC5

Spnntaneous emission from active dielectric microstructures. Thomas Sendergaard and Bjarne Tromborg

Research Center COM, Technical University of Denmark, Building 349 . DK-2800 Kgs. Lynghy, Denmark, Telephone: +45452537 89, Fax: +4545936581 , E-mail: reacom.dru.dk

Spontaneous ernission is one of the key factors that determine the noise properties of photonic devices and the purmp power threshold of lasers. The spontaneous emission in dielectric extend be controlled and engineered due to the denendence of the emission rate on the location and polarisation of the emitters in the structure [1,2]. This paper addresscs the methods of quantum electrodynamies of dielectric media which enable calculation of the local rate of spontaneous emission in active microstructures.

For passive structures the spontaneous emission may be derived by expanding the radiation field in power-orthogonal modes normalized to one quantum of energy, and using the Fermi Golden Rule. This approach was used in [1] for calculating the position dependence of spontaneous emission in passive photonic crystals. However, for active materials the mode the field operators and and is $\Gamma=\frac{2 \mu_{0}}{h} \ln \left(\left[\left\langle\vec{j}^{+}(\vec{r}) \cdot \bar{G}\left(\vec{r}^{\prime}, \vec{r}^{\prime}\right) \cdot \vec{j}\left(\vec{r}^{\prime}\right)\right\rangle d^{1} \vec{r}^{\prime} d^{1} \vec{r}^{\prime \prime}\right)\right.$

where $\bar{j}(\bar{r})$ is the generating current, and $\bar{G}\left(\bar{r}^{\prime}, \vec{r}\right)$ is the classical transverse Green's tensor that determines the electric field in terms of the transverse current For materiags with win the tensor can be derived from the solutions to the homogeneouss wave equation and the adjoint wave equation.

As an example we show in Figure 1, in polar coordinates, the distribution of spontancous emission going into radiation modes from an active optical fiber. The distributions are show for the eminer in the center of the fiber core and at the edge of the fiter core, respectively. The optical fiber has the core refractive index 1.45 , cladding refractive index 1.43, core radi $2 \mu \mathrm{m}$. The emission wavelength is $1508 \mathrm{~mm}$. The emission rate $\Gamma_{z}$ is for dipoles with orientation along the fiber axis, $\Gamma_{1}$ is the sum of emission rates for dipoles with orientation perpendicular to the fiber axis, and $\Gamma_{p a r}$ is the sum of these two emission rates.

The presentation will include an analysis of the effects of gain on the radiation pattern and the ratio of radiation into the guided mode(s) for active optical fibers.

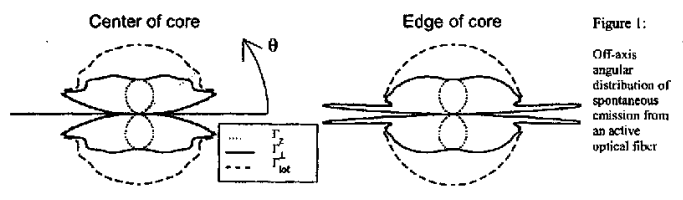

[1] T Sendergard, "Spontaneous emission in two-dimensional photonic erystal microcavities", to appear EEEE Jourmal of Qunnturn Elocteonics Aprii 2000 [2] S.M. Hametl, B. Hutther, R. Loudon and R. Malloob, "Decay of exited atoms in absorting dielectrics",
Phys. B: At Mol. Opt. Phys . vol. 29, pp. 3763-378t, 1996. 